considerations suggest that the only nations yei equipped to wage biological warfare at all successfully are those already possessing sophisticated technology. Although biological warfare is cheaper and easier than nuclear war, it is still far from being the poor man's weapon.

Biological weapons are therefore most likely to be deployed by powers which already have nuclear weapons at their disposal. This, of course, reduces greatly the danger that they will ever be deployed at all, for it would be quite possible for the victims of an attack to retaliate with nuclear weapons. In the event of a major power attacking a lesser one, of course, this

\section{How Not to Save Money}

ON August 7 the three man mission from the International Monetary Fund returned to Washington after spending a suspiciously long time in formal talks with the British Treasury. The mission was in Britain to examine the progress of the British economy since devaluation and in particular to satisfy itself that Government spending was being contained within the limits set by the Prime Minister in his January 16 speech to the House of Commons, in which he announced cuts of $£ 300$ million in public expenditure. The IMF, obviously concerned at the way public spending was creeping above the ceiling set in January, wanted assurances that the summer cuts, quietly decided on by the Government before the end of the Parliamentary session, were adequate. No doubt to save itself from further unpopularity and embarrassment, the Government has decided not to announce its new package of economies publicly. Instead, local authorities and government agencies will simply find that authorizations for spending on specific projects will be delayed or stopped indefinitely.

Instead of making a clean breast of its decisions to the public as well as to the IMF, the Government has decided to keep its policy secret. It prefers to weather a series of minor storms, rather than face a major outcry. Perhaps, with Parliament in recess, the holiday season in full swing and the IMF mission back home fully briefed and apparently satisfied, the Government hopes many of its measures will pass more or less unnoticed.

For the second time in a year and probably the fourth time in three years the universities have been asked to cut back their capital expenditure programmes. In January the UGC got away with what must now seem a very small cut in its capital grants fund for 1968-69; it was reduced by $£ 5$ million, roughly one sixth of the total. The UGC dutifully passed this cut on to the universities by, as it says, stopping certain projects in certain universities. Sticking to its peculiar belief in silence, the UGC refuses to say which universities were affected in January. Now it has been told to stop all new capital expenditure.

The UGC sent a private letter on August 1 to all vice-chancellors, most of whom, as luck would have it, happened to be in Melbourne attending a meeting of argument does not apply with equal force. But the major powers have long been in the position of being able to attack lesser ones with nuclear weapons, and have not yet done so; the situation is thus no worse than before, if that is any consolation. The real fear, that biological weapons will be used in border skirmishes (just as chemical weapons are already said to have been used in the Yemen), is probably not very likely, given the present uncertainties about delivery, and the best way of preventing it remains the conventional one. The balance of terror between the great power blocs may not be to everybody's taste, but it is probably still the best way of avoiding war.

the Association of British Commonwealth Universities. The letter instructed them not to begin any new projects after August 1. The UGC has not published and does not intend to publish the letter. Perhaps, as one vice-chancellor has said, it was as embarrassed at having to send the letter as the vice-chancellors were at having to receive it. All building started before August 1 or covered by a firm contract, letters of intent or orders to proceed will be unaffected, but all new projects will be stopped. The UGC, in an attempt to mitigate some of the disastrous effects a complete ban would have, is prepared to consider claims to start urgent projects. That means, apparently, conversion or adaptation of existing buildings, buildings which were being built with prefabricated units which have already been ordered, projects which if stopped would prevent existing students from completing their courses, and pre-clinical projects attached to hospital building schemes.

Neither the Government nor the UGC is prepared to say how much they hope to save; indeed, nobody yet seems to know how much the new restriction will in fact save. But it is rumoured that the target may be as high as half the year's total allocation of $£ 29$ million. The vice-chancellors have been asked to send details of the projects they have been obliged to stop, and there is the threat that if the amount saved is less than the Government hopes, there will be a further 5 per cent cut on all capital and equipment grants. Until the vice-chancellors have made their returns, it is difficult to assess which universities have been hardest hit, but the whole business is being run like a lottery. Whether or not universities get their buildings depends not on how badly they are needed but on the date the contracts were signed. Many universities, like York, Canterbury and Durham, have recently signed contracts. Others, like Surrey, recently upgraded to university status and in the middle of moving from London to Guildford, are likely to be badly disappointed.

\section{Postal Chaos}

THE American postal system is inefficient, disorganized and costs the taxpayers over $\$ 1,000$ million a year. In 
short, it faces a crisis. So says the report of a presidential commission on postal organization published recently (Towards Postal Excellence, US Government Printing Office, $\$ 1 \cdot 25$ ). The results are not surprising, but any radical change in the present system certainly will be. The commission calls for a total reorganization of the postal service on a self-supporting, non-political basis-a federally owned corporation operating like any other big business, supporting itself from its revenues, able to borrow in its own name to finance modern facilities and quick to identify and meet new market demands.

These recommendations may seem obvious and long overdue, especially to the British observers, whose post office already reflects a business-like approach, but the present system is well entrenched in the United States and too many interests, especially Congress and the President, stand to lose by any major structural changes. President Johnson guardedly called the report "a sobering judgment on what is required to provide excellence in postal service in the years ahead" and passed it on to his most recent appointee as Postmaster General, Marvin Watson--a former White House staff member and fellow Texan.

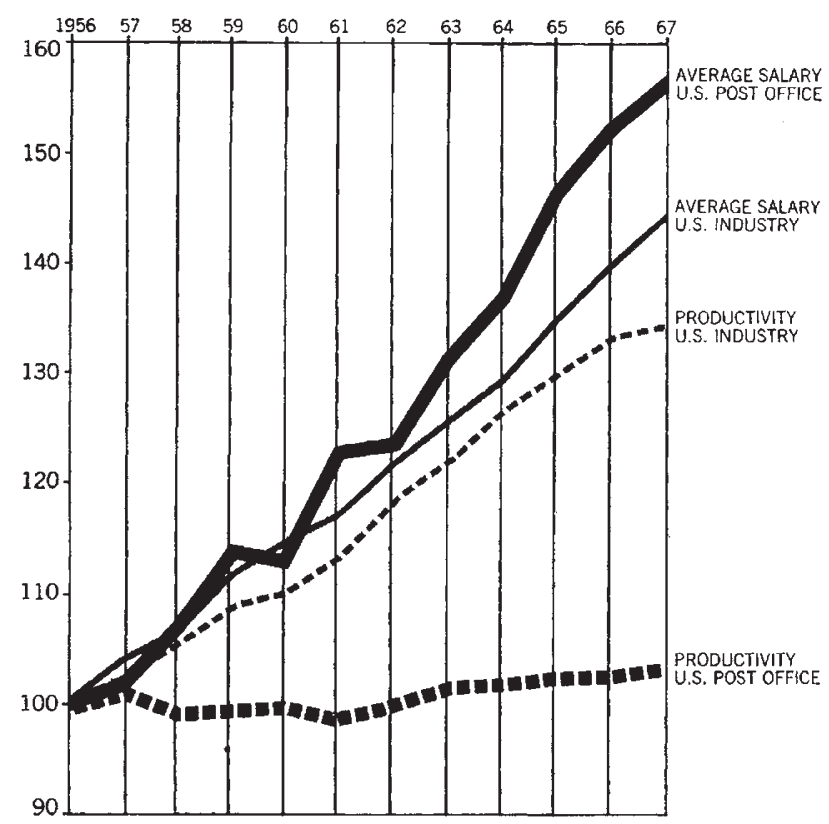

Productivity and salaries in the US Post Office.

The commission, chaired by Frederick Kappel, retired chairman of the American Telephone and Telegraph Company, and including George Baker, dean of Harvard's School of Business Administration, had only praise for the employees themselves but felt that they were fighting a losing battle against an outmoded system. Lawrence F. O'Brien, Postmaster General at the time of the study, called the present operation a "race with catastrophe", but with nearly 80,000 million pieces of mail handled last year and a 41 per cont increase expected within ten years, catastrophe should be well in the lead before long. On the other hand, the commission estimated that postal costs could be reduced by at least 20 per cent and the entire postal deficit eliminated within a few years if the service were run on the same managerial basis as that used by private industry.

For a start, the only political appointments would be six of the nine members of the board of directors, appointed by the President and confirmed by the Senate. These six would then select the three executive members of the board, and the board as a whole, rather than Congress, would have the final authority to run the postal system. The present personnel system is at least two to three decades out of date-it now takes 13 weeks to hire an employee, and a recent survey showed that 67 per cent of applicants in large cities did not wait around to complete the process. Career opportunities are limited-more than 80 per cent of all employees finish their career in the same grade level at which they started; an employee cannot earn promotion by merit, he cannot rise except within his original area, and without political help he cannot even rise to the top of his own post office; and the present system of supervision results in management "by the book" - "that some postmasters and supervisors do well is a tribute to them as individuals, not to the system they are able to outwit".

The financial picture is equally bleak-no postmaster sees information about the total costs of his operations (and indeed such figures seem not to exist) and operations are conducted strictly on a man-hour basis so there is no incentive to invest in labour-saving machines. Appalled by the lack of such basic informa. tion, the commission called for a management information network to report the real operating costs and management control to motivate all workers toward cost-conscious operation. More savings should come, in the report's view, from an overhaul of the present irrational postal rate system. The present rates are set by Congress using a 43 year old cost ascertainment system in which every postal expense is charged, often arbitrarily, to a particular class of service. Instead, the commission recommends that the corporation forward rate proposals to a panel of technically qualified postal rate commissioners who in turn would review expert testimony from economists, engineers and accountants before sending their decision back to the board for final consideration. Congress would then have sixty days to veto the proposed rates. The commission emphasized that revenues from each class of mail must cover the full costs of providing the service; remaining institutional costs would be apportioned on the basis of market factors such as the nature of the services and the differing demand. These recommendations are likely to prove the most difficult to put into effect, although they would benefit the largest number of people, because Congress will be under strong pressure from the powerful business lobbies that have long benefited from the heavily subsidized rates for newspapers and advertising.

\section{Number Crunching}

THE British computer industry chose the meeting in Edinburgh last week of the International Federation of Computer Processing to flex some of its newly found muscles. International Computers Limited (ICL), the company formed in March this year by International Computers and Tabulators, English Electric and Plessey announced a new machine more powerful than Atlas by a factor between seven and ten, depending on 